\section{Nitrogen Supply during Production of Tomato Transplants Affects Preference by Colorado Potato Beetle}

\author{
D.W.A. Hunt, A. Liptay, and C.F. Drury \\ Agriculture Canada, Research Station, Harrow, Ontario NOR 1G0, Canada
}

Additional index words. acclimatization, Leptinotarsa decemlineata, Lycopersicon esculentum, greenhouse

\begin{abstract}
Host plant selection by Colorado potato beetle [Leptinotarsa decemlineata (Say)] was examined on tomato [Lycopersicon esculentum Mill.] transplants fertilized with varying $\mathbf{N}, \mathbf{P}$, and $K$ concentrations during greenhouse production. In choice tests conducted with beetles in the field and the greenhouse, the insect preference for plants increased with increasing leaf tissue $N$ concentration, but $P$ and $K$ concentrations had no effect. Five-day, seedling acclimatization to outdoor spring temperatures before planting reduced the insect preference for plants.
\end{abstract}

Nitrogen fertilization of crop plants influences host selection by insect pests and also affects the pests' survival, growth , and reproduction rates (Scriber, 1984). Survival of Colorado potato beetle larvae on nightshade (Solanum dulcamara L.) was positively correlated with extractable protein concentration in the foliage from late spring to midsummer (Hare, 1983). In one study, variation in the amount of $\mathrm{N}$ applied to 'Katahdin' potato (Solanum tuberosum L.) did not influence the abundance of Colorado potato beetle under field conditions, and beetle development rate was negatively correlated with foliar $\mathrm{N}$ content (Jansson and Smilowitz, 1985). However, in a comparison of potato cultivars, Jansson and Smilowitz (1986) found a positive correlation between the number of Colorado potato beetles and the foliar $\mathrm{N}$ content. Nitrogen content of laboratory-reared larvae and drymass gain of greenhouse-reared larvae were positively correlated with increasing $\mathrm{N}$ concentration applied to potato plants, yet other insect growth attributes were not affected (Zitzman and May, 1989). Increasing the protein concentration of artificial diets resulted in increased growth of Colorado potato beetle larvae (Hare, 1987); moreover, high protein concentrations could offset the effect of high glycoalkaloids concentrations that act as feeding deterrents in the Solanum species. Percent survival, development rate, and pupal weight of Colorado potato beetle were positively correlated with tomato plant $\mathrm{N}$ concentration (Hunt et al., 1992).

The Colorado potato beetle is a serious pest of cultivated tomato, particularly during the first few weeks following field setting. Literature reports on the effects of $\mathrm{N}$ fertilization of solanaceous plants on Colorado potato beetle are contradictory, and we could find no infor-

Received for publication 14 Jan. 1994. Accepted for publication 27 June 1994. The cost of publishing this paper was defrayed in part by the payment of page charges. Under postal regulations, this paper therefore must be hereby marked advertisement solely to indicate this fact. mation about the effects of $\mathrm{N}$ concentration in tomato on host preference. Therefore, our objective was to determine if Colorado potato beetles show a preference for tomato seedlings grown with various $\mathrm{N}$ fertilization rates. In addition, we assessed whether the preference changed after outdoor acclimatization of seedlings, a practice commonly used by growers in temperate areas.

\section{Materials and Methods}

Plant material. 'Ohio 8245' tomato seeds were sown in modified peatmoss (ASB, ASBGreenworld, Pointe Sapin, New Brunswick, Canada) in 288-celled trays (tray dimensions, $25 \times 52 \mathrm{~cm}$; cell volumes, $\left.6 \mathrm{~cm}^{3}\right)$. The seeded trays were held in a greenhouse $(26 \pm 2 \mathrm{C}, 16$ $\mathrm{h}$ day; $18 \pm 2 \mathrm{C}, 8$-h night) without supplemental light. We produced equal-aged seedlings containing various $\mathrm{N}$ concentrations by providing mineral solutions (in $\mathrm{mg} \cdot$ liter $^{-1}$ ) having common $10 \mathrm{P}-250 \mathrm{~K}-100 \mathrm{Ca}-40 \mathrm{Mg}$ levels but with varying $\mathrm{N}$ (i.e., 0, 30, 60, 90, 120, 150, $180,210,240,270$, or 300$)$. These mineral solutions were supplied five times weekly at $300 \mathrm{ml} /$ tray beginning the 10th day after sowing; tap water was used as required at other times.

Because the previously described $11 \mathrm{~N}$ treatments were expected to yield seedlings that varied in size and $\mathrm{N}$ concentration, tests also were conducted using tomato transplants of the same size that contained different $\mathrm{N}$ concentrations. Seedling size was regulated by varying the seeding date, $\mathrm{N}$ nutrition, and watering. Trays were seeded every second day, and later seeding dates received more frequent $\mathrm{N}$ applications and watering. Seedlings from six of the seeding dates were used that were of equal height and had widely different tissue $\mathrm{N}$ concentrations.

In another experiment, we produced seedlings containing various $\mathrm{P}, \mathrm{N}$, and $\mathrm{K}$ concentrations. Phosphorous was added at $0,5,10$, 15, 20, and 25 mg.liter ${ }^{-1} ; \mathrm{N}$ at 0, 40, 80, 120, 160, and $200 \mathrm{mg}^{-1 i t e r^{-1}}$; and $\mathrm{K}$ at 30, 90 and $150 \mathrm{mg} \cdot$ liter $^{-1}$.
In one treatment, tomato seedlings were acclimatized to cool weather by placing the plants outdoors for 5 days before field setting. The maxima and minima temperatures recorded during these 5 days were (in C) 12,5 ; $12,4.5 ; 12,0 ; 12,6$; and $14.5,8.5$. Nonacclimatized control seedlings were planted directly from the greenhouse to the field.

Preference tests conducted in the field. Tests of Colorado potato beetle preference for seedlings containing various $\mathrm{N}, \mathrm{P}$, and $\mathrm{K}$ concentrations, with and without acclimatization to cool weather, were conducted in May 1993 using 7-week-old transplants planted in twinrowed beds in the field. Thirty plants per treatment were spaced $30 \mathrm{~cm}$ apart, with $1 \mathrm{~m}$ between beds; each treatment was replicated four times. Adult beetles were allowed to naturally infest the field; we collected the beetles from plants three times weekly for the first 3 weeks after planting and then removed them from the field. Counts from the various dates were pooled to obtain a mean number of beetles per plant.

Preference tests conducted in the greenhouse. For the $11 \mathrm{~N}$ treatments, preference tests also were conducted in ground beds in a greenhouse in $3.7 \times 3.7 \times 1.8$-m cages covered in $20 \times 20$ mesh screen (Sullivan and Brampton, San Leandro, Calif.) at 23 to $26 \mathrm{C}$ using natural light. In one test (long range preference), 7week-old tomato transplants were placed into a $3 \times 3$ grid in each of 11 plastic multicelled trays, with $11 \mathrm{~cm}$ between seedlings. Each tray received seedlings from one of the $11 \mathrm{~N}$ treatment. The 11 trays were placed uniformly around a ground bed enclosed by a screen cage, and each tray was buried to just below ground level. Twenty-five, field-collected, Colorado potato beetles were released from each of four petri dishes arranged around the grid of trays. After $\approx 2 \mathrm{~h}$, the insects were collected from the screen cage and beetles that were within seedling trays were counted as preferring that treatment. The experiment was repeated 30 times, and the distribution of the 11 treatments was completely randomized within the screen cage for each repetition.

In a second greenhouse test (short range preference), one seedling from each of the same $11 \mathrm{~N}$ treatments was placed in a $4 \times 3$ grid, $11 \mathrm{~cm}$ from the other seedlings, within a single buried multicell tray. One hundred fieldcollected, adult, Colorado potato beetles were released within the tray and a $60 \times 60 \times 55-\mathrm{cm}$ cage was placed over the tray to keep the beetles near the plants. The insects were collected after $\approx 2 \mathrm{~h}$, and beetles that were on seedlings were counted as preferring that treatment. This test also was repeated 30 times.

Plant analysis. Ten plants from each of the $\mathrm{N}$ treatments were harvested at the time of field planting. These plants were individually dried at 80C, ground using a Wiley mill (Arthur H. Thomas Co., Philadelphia) with a 0.419mm sieve (40 mesh), and a Kjeldahl digestion was performed. The digests were analyzed on an autoanalyzer (model TRAACS 800; Bran + Luebbe Analyzing Technologies, Buffalo Grove, Ill.) for $\mathrm{NH}_{4}^{+}$using the Berthelot reaction. 


\section{Results and Discussion}

The $\mathrm{N}$ fertilization regime significantly affected the Colorado potato beetle's preference for tomato seedlings. In field tests, beetles were more abundant on seedlings containing higher $\mathrm{N}$ levels (Fig. 1). In the greenhouse, there was a strong correlation between tomato seedling $\mathrm{N}$ concentration and the number of beetles in both experiments. For experiments where a $\mathrm{N}$ treatment was located in each tray, the regression equation was $\mathrm{Y}=0.86 \mathrm{X}+$ 15.23, $r^{2}=0.88, P \leq 0.0001$, and for those where a $\mathrm{N}$ treatment was located in each cell within a tray, it was $\mathrm{Y}=0.89 \mathrm{X}+14.94, r^{2}=$ $0.86, P \leq 0.0001$. The consistency of the results for field tests and greenhouse tests conducted in large and small cages suggests that long- and short-range host-orientation of the Colorado potato beetle are involved in the beetle preference for higher $\mathrm{N}$ levels.

As would be expected, seedlings that received higher $\mathrm{N}$ levels were larger. In the $11 \mathrm{~N}$ treatments, average seedling heights at 55 days were ( $\mathrm{N}$ level in $\mathrm{mg} \cdot \mathrm{liter}^{-1}$ and height in $\mathrm{cm} \pm \mathrm{sE}): 0=3.7 \pm 0.16 ; 30=3.8 \pm 0.14 ; 60=$ $5.1 \pm 0.11 ; 90=6.9 \pm 0.25 ; 120=7.9 \pm 0.39$; $150=10.8 \pm 0.51 ; 180=12.8 \pm 0.58 ; 210=$ $14.9 \pm 0.30 ; 240=15.1 \pm 0.25 ; 270=17.5 \pm$ $0.29 ; 300=18.3 \pm 0.31$.

Preference tests conducted with transplants of the same size but containing different $\mathrm{N}$ levels also demonstrated a beetle preference for higher $\mathrm{N}$ concentration (Fig. 2). This finding suggests that the beetles in the previous test (Fig. 1) were attracted to plants because they had higher $\mathrm{N}$ levels, not because they were taller. Beetles did not show any differential preference for tomato seedlings grown with various $\mathrm{P}$ and $\mathrm{K}$ levels (data not shown). The slopes obtained from regression equations of beetle preference for acclimatized and nonacclimatized seedlings were significantly different $(P \leq 0.001)$. This finding indicated that seedlings that were acclimatized to low temperatures for 5 days before field setting were less acceptable to the Colorado potato beetle than nonacclimatized seedlings, particularly for higher $\mathrm{N}$ treatments (Fig. 3).

When Colorado potato beetles were allowed to select from plants with different $\mathrm{N}$ concentrations, the beetles prefer seedlings that contain higher N levels. Hunt et al. (1992) established that Colorado potato beetles that developed on tomato plants that had received higher $\mathrm{N}$ levels had a higher percent survivalto-adult rate, developed more rapidly, and weighed more as pupae. Our study on the host preference shown by the Colorado potato beetle suggests that this increase in performance is accompanied by the ability of adult beetles to differentiate between plants with a range of $\mathrm{N}$ levels.

Although our results establish that applying increased $\mathrm{N}$ levels and the resultant increases in foliar $\mathrm{N}$ content resulted in increased Colorado potato beetle preference for tomato plants, we do not know which plant characteristics are involved. The increased preference may be due to changes in leaf color, plant odor, plant shape, amino acid composi-

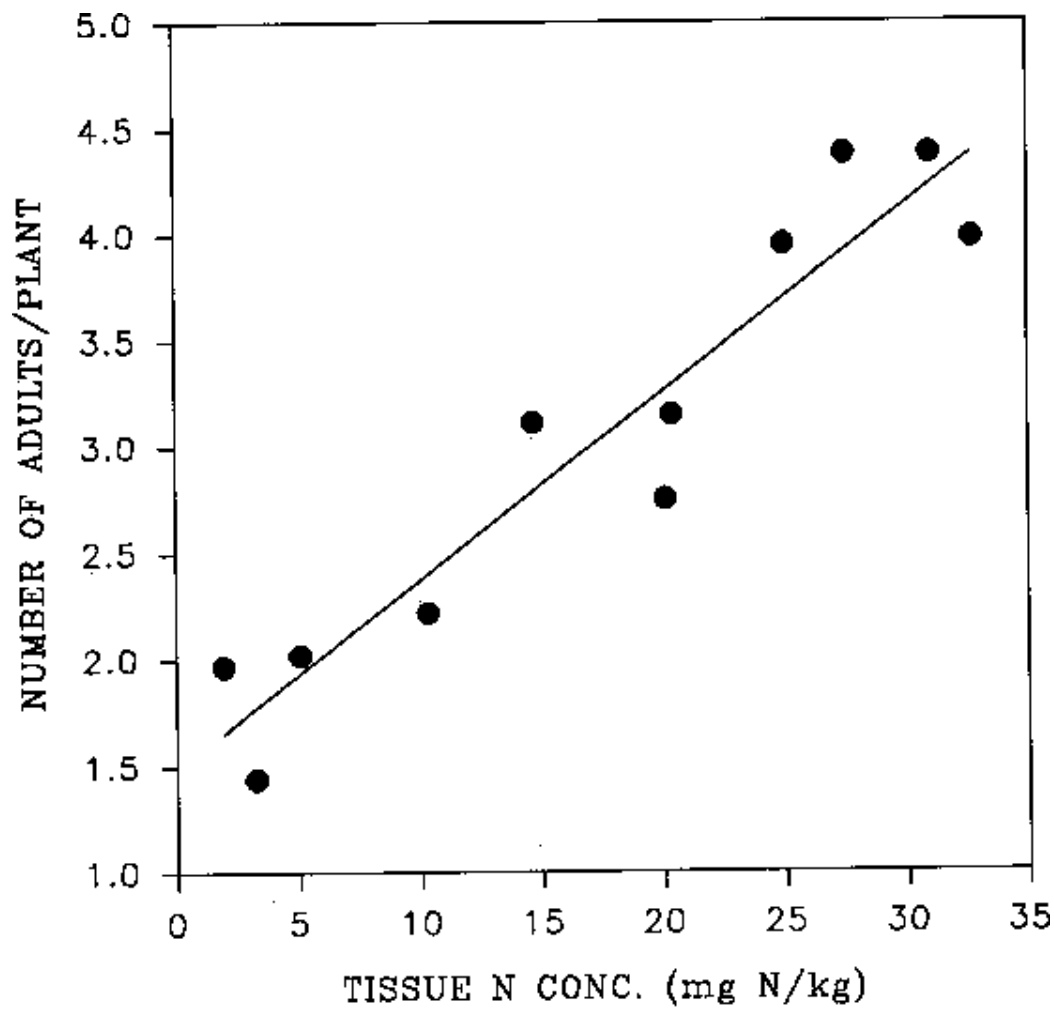

Fig. 1. Regression of $\mathrm{N}$ concentration in tomato transplants and mean number of Colorado potato beetle adults collected per plant in the field, where $\mathrm{Y}=0.088 \mathrm{X}+1.490, r^{2}=0.90, P<0.0001$. Plants were treated with $11 \mathrm{~N}$ levels. Seedling height increased (see text) with increasing N supplied to the transplants during greenhouse production.



Fig. 2. Regression of $\mathrm{N}$ concentration in tomato transplants and mean number of Colorado potato beetle adults collected per plant in the greenhouse, where $\mathrm{Y}=0.099 \mathrm{X}+3.202, r^{2}=0.76, P<0.02$. Transplants from all treatments were grown to the same height by varying the seeding date, $\mathrm{N}$ nutrition, and watering. 


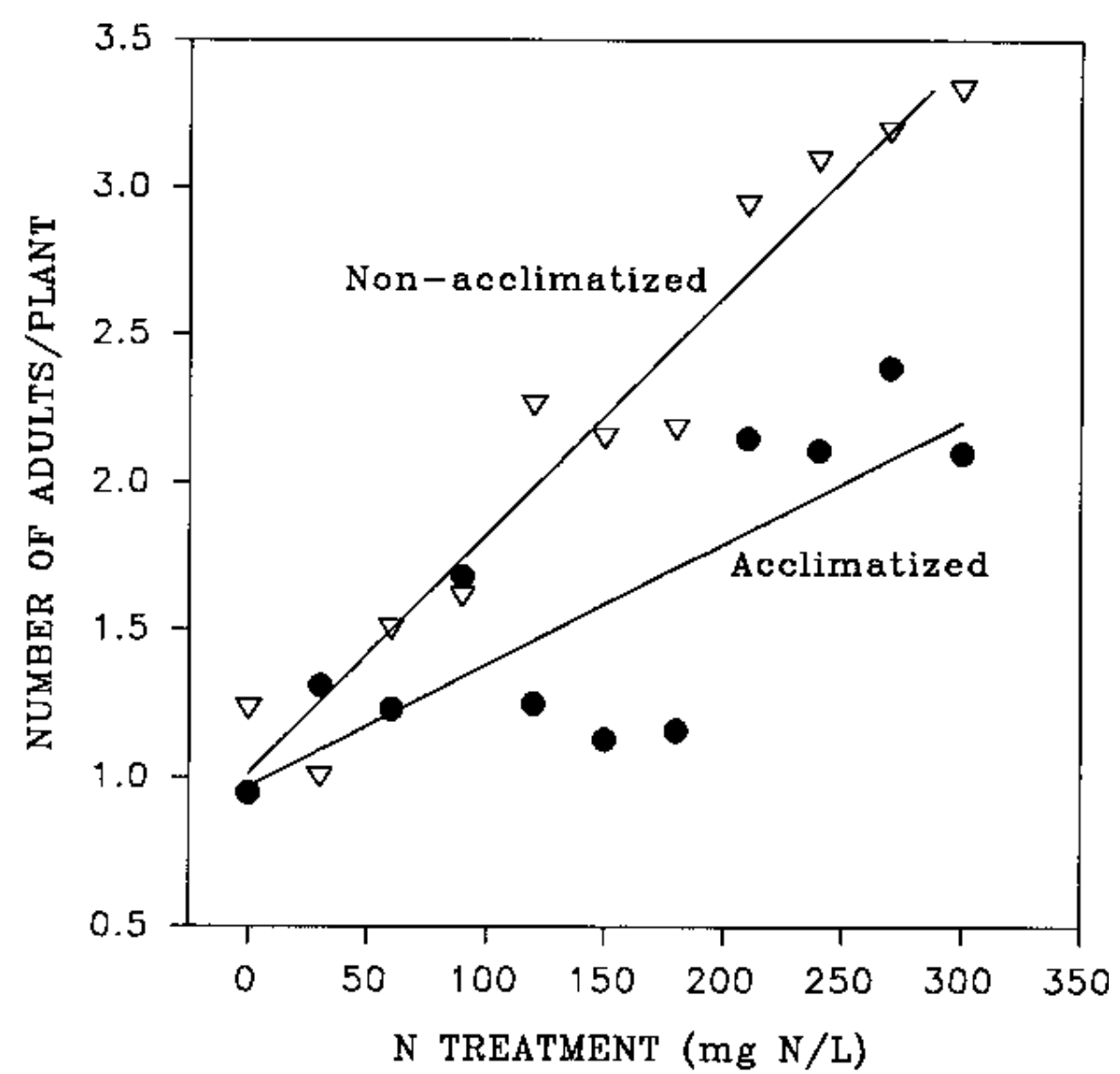

Fig. $\hat{3}$. ’̉egression of $\mathrm{N}$ applied to tomato transplants (in mililigrams per liter) and mean number of Colorado potato beetle adults collected per plant in the field. For nonacclimatized plants, $\mathrm{Y}=0.008 \mathrm{X}+1.016, r^{2}$ $=0.94, P<0.0001$; for acclimatized plants, $\mathrm{Y}=0.004 \mathrm{X}+0.971, r^{2}=0.64, P<0.0032$.

tion, secondary plant substances, or other factors.

Exposing tomato seedlings to cool outdoor conditions for 5 days increased the stem stiffness of the seedlings (A.L., unpublished data). Tomato growers in areas with cool spring weather commonly acclimatize seedlings be- ity exists of effectively reducing Colorado potato beetle infestations through modification of the plant-making it less attractive to the insect. Other treatments that increase the toughness of tomato seedlings and the effects of these treatments on the acceptability of seedlings to the Colorado potato beetle are worthy of study.

\section{Literature Cited}

Black, C.A. 1968. Soil-plant relationships. Wiley, New York.

Hare, J.D. 1983. Seasonal variation in plant-insect associations: Utilization of Solanum dulcamara by Leptinotarsa decemlineata. Ecology 64:345361.

Hare, J.D. 1987. Growth of Leptinotarsa decemlineata larvae in response to simultaneous variation in protein and glycoalkaloid concentration. J. Chem. Ecol. 13:39-46.

Hunt, D.W.A., C.F. Drury, and H.E.L. Maw. 1992. Influence of nitrogen on the performance of Colorado potato beetle (Coleoptera: Chrysomelidae) on tomato. Environ. Entomol. 21:817-821.

Jansson, R.K. and Z. Smilowitz. 1985. Influence of nitrogen on population parameters of potato insects: Abundance, development, and damage of the Colorado potato beetle, Leptinotarsa decemlineata (Coleoptera: Chrysomelidae). Environ. Entomol. 14:500-506.

Jansson, R.K. and Z. Smilowitz. 1986. Influence of potato persistence, foliar biomass, and foliar nitrogen on abundance of Leptinotarsa decemlineata (Coleoptera: Chrysomelidae) on potato. Environ. Entomol. 15:726-732.

Scriber, J.M. 1984. Nitrogen nutrition of plants and insect invasion, p. 441-460. In: R.D. Hauck (ed.). Nitrogen in crop production. Amer. Soc. Agron., Madison, Wis.

Zitzman, A., Jr., and M.L. May. 1989. Growth, food consumption, and nitrogen and lipid compositions of the Colorado potato beetle, Leptinotarsa decemlineata (Coleoptera: Chrysomelidae) as a function of the nitrogen supply of its host plant. J. Entomol. Sci. 24:62-69. 